\title{
Syria, Productive Antinomy, and the Study of Civil War
}

\author{
Jonah Schulhofer-Wohl
}

Civil War in Syria: Mobilization and Competing Social Orders. By Adam Baczko, Gilles Dorronsoro, and Arthur Quesnay. New York: Cambridge University Press, 2018. 336p. \$84.99 cloth, \$27.99 paper.

$T$ he horrors of the ongoing Syrian civil war have never been far from the front pages of the news. Social scientists who wish to study it soon confront the awkward reality that the war's ferocity precludes field research on its central military and political dynamics. Scholars have made important advances in studying mechanisms behind protest activity and the mobilization of armed opposition to the al-Assad regime, but much work is confined to studying the conflict through the lens of refugees. Adam Baczko, Gilles Dorronsoro, and Arthur Quesnay's research is all the more indispensable for that context. Scholars of civil war and of autocracies, researchers investigating the 2011 Arab uprisings, and Syria specialists all will find value in their book's rich pairing of theoretically-driven analysis and empirical material gathered through field research in Syria.

The book investigates three broad topic areas: the onset of large-scale anti-regime protests and their transformation into violent contention; the emergence of territorial entities governed by separate armed actors and the institutions therein; and war-driven changes in the value of economic, social, cultural, and identity capitals. The main text covers each topic (Parts I, III, and IV) and details the opposition's structure and means of sustenance, particularly the development, organization, and maintenance of armed groups (Part II). A brief concluding chapter reflects on the course of events in Syria in light of the authors' arguments.

The Bourdieusian sociological approach of Baczko, Dorronsoro, and Quesnay stands apart from the dominant paradigm of civil war studies yet still maintains a productive dialogue between extant arguments and the

Jonah Schulhofer-Wohl is Assistant Professor of Politics at the University of Virginia and Research Associate at the Middle East Initiative, Belfer Center for Science and International Affairs, Harvard Kennedy School. authors' accounts of the phenomena in question. The chapter on anti-regime protest, for example, contrasts relative deprivation, resource mobilization, moral shock, and rational choice-based explanations with the authors' own model of "mobilization through deliberation" (pp. 73-83). Here, three factors are seen as having enabled the mass protests: the opportunity that the "Arab Spring" context afforded Syrians to discuss and generate meaning surrounding anticipated anti-regime actions; the narrowing effect of regime repression on protestors' options, which paradoxically reinforced continued participation; and the ability to coordinate using varied modes of communication, from the Internet to strong face-to-face ties facilitated by imprisonment or shared participation in risky protest activity.

The book's power lies in the "more than 250 " semistructured interviews that the authors conducted, mostly during two trips to opposition-controlled territory in north and northeastern Syria (December 2012-January 2013 and August 2013), and during research in Turkey, France, Iraq, Lebanon, Jordan, and Egypt (p. 30). 162 of these are cited in the book and helpfully catalogued in an appendix. The relevant table (pp. 272-84) provides the location and date of the interview, and the gender, sect, ethnicity, place of origin, prewar profession or social status, and wartime activities of the respondent. The interviews are notable for the authors' adroit use of a team methodology, unusual given the typical single researcher model in interview-based studies of civil war. All three scholars participated but in different roles, which they rotated across interviews. In addition to standard note-taking and questioning tasks, these included observation. In a final stage, the authors deliberated as a team regarding their interpretation of the interview's content (p. 32).

The authors integrate the interviews seamlessly throughout the book. The material is versatile and portrays a vigorous Syrian society during the transformative 2011-13 years. Chapter 12 explains the ways in which the war fragmented Syria's economy and local adaptation 
to the resulting challenges. In Chapters 4 and 5, we learn about foreign and domestic funding of armed opposition groups (pp. 110-11), the creation of courts and standardization of procedure and legal codes across them (pp. 120-22), the character of local administration in opposition-controlled territory, and even differences between regime military and police personnel in the means of defection (pp. 104-5, 126).

The authors' insights into Syria at war, however, contrast with a theoretical approach that may hinder more than it assists their investigations. The prefatory chapter illustrates this. Its vehement critique of positivist and rational choice research on civil war, i.e. much of the research carried out in political science, sociology, and economics going back decades, and nearly all current studies, prompts the authors to lay out an alternative sociological approach. They begin from the beginning, with a new definition of civil war: "the coexistence on the same national territory of competing social orders engaged in a violent relationship" (p. 18). Notably, this definition excises the state and politics, at least in those terms, putting it at odds with contemporary definitions in political science, in which the rupture of sovereignty constitutes a shared core (for example, see Harry Eckstein's "On the Etiology of Internal Wars," History and Theory 4(2), 1965). Innovation is not inherently problematic. But the difficulty is that it is unclear that the authors' definition provides additional analytic traction, while, at the same time, it introduces the danger that studies based on it will talk past research that follows the standard paradigm. In addition, if taken literally, the authors' definition is so broad as to be indiscriminate. Is there a single country that at present does not experience some form of "competing social orders in a violent relationship," when the authors define "social order" as "an economy of violence, relative values of capitals, and relations between fields at varying degrees of institutionalization" (p. 18) and leave "violent relationship" undefined? While the authors take existing research to task for potential pitfalls like the use of fatalities thresholds to determine whether political violence is sufficiently large-scale to constitute civil war, they prescribe a cure worse than the disease.

Indeed, there is much to suggest common ground between the positivist and rational choice paradigms and the authors' approach. In the prefatory chapter, they articulate what they view as vast differences between the two (pp. 21-22):

Against the neopositivist model of the isolated individual, we will stake up an agent that is socially grounded (gender, class, dispositions to act, and body hexis) and involved in daily interactions. We distinguish three aspects: socialization, the political context, and the interaction setting. The agent calculates the risks and odds of success, but this strategic aptitude depends on his socialization and available resources (information, time, money), which allow him to interpret the context and, more immediately the interaction setting. He deliberates, meaning that he generally makes his decisions following interactions during which he forms his judgment. Furthermore, he referees different ends, which regardless of whether they are collective or individual, altruistic, or egoistical ones, imply an ethic and values. Finally, in contrast to a static vision of individuals and their preferences, we assert that the context transforms the agent's dispositions, competences, and decision-making processes. We therefore analyze successively the transformation of his dispositions to act, the learning of competences, and, finally, the transformation of decision-making processes.

A game theorist would recognize these ideas and consider them possible to model (and, if some seem incompatible with rational choice, pages $22-23$ provide details). One wonders, then, whether the authors' discounting of positivism and rational choice led to unnecessary blind spots. For example, their analysis of the ways in which war changed or failed to change women's social roles (pp. 234-38) would have benefited from engaging with Jocelyn Viterna's Women in War: The Micro-Processes of Mobilization in El Salvador (2013). A chapter on the "identity regimes" that corresponded to territories according to the armed actor in control (the authors distinguish between the al-Assad regime; "the revolution," i.e. most of the armed opposition; the Kurdish Democratic Union Party (PYD); and the Islamic State) is tantalizing. It might have shed additional light on patterns of violence within these territories had the authors applied Roger Petersen's arguments about the emotional mechanisms of fear, hatred, and resentment, particularly the latter's attention to social identity hierarchies (see his Understanding Ethnic Violence: Fear, Hatred, and Resentment in Twentieth Century Europe, 2002).

Baczko, Dorronsoro, and Quesnay do not set out to test falsifiable hypotheses. As a result, however, the reader is left to wonder what empirical material they would have understood as disconfirming their theoretical apparatus. Chapter 11 illustrates this point. The authors interpret all changes in Syrians' lives as representing losses (or gains) in the value of capital due to wartime conditions. Might such changes occur and leave the value of capital untouched? They do not consider this possibility; more generally, they do not consider alternative explanations that might be consistent with the pattern of facts that their interviews uncovered.

For readers unfamiliar with Syria, it is worth pointing out that the authors' interpretations, their presentation of its history, and their assessment of current works on it can at times be unusual. For example, in an otherwise excellent chapter on "The Building of Military Capital," they overinterpret the organizational terminology used by the armed opposition. They construe the Arabic terms for different-sized military formations, even the word for commander, as having been "borrowed ... from the Syrian army," as many of the opposition's military leaders were defectors. The authors find this borrowing to be "an 
explicit case of 'vulgarisation of power' with an acute awareness on the part of actors of the state formation process they are taking part in" (p. 108 n. 22). They also contend that the terms "tapped into anti-colonialism dating from the time of the Mandate" (pp. 108-9). Unfortunately, they provide no material from their interviews or other sources to substantiate these two assertions. In their zeal to "explain" Syria, they appear to have overlooked the possibility that the terms may have been used because they were the accurate linguistic representation of the organizational concepts to which they referred.

The book barely mentions the political violence of the late 1970s and early 1980s, and never acknowledges it as a civil war. Instead, there are oblique references to the regime's 1982 massacre of its citizens in Hama (p. 34) or its deployment of "Kurdish militias against the Muslim Brotherhood" in the early 1980s (p. 60). A puzzling omission is the book's lack of reference to one of the most significant analyses of Hafiz al-Assad's ascent to power, autocratic rule, and the complex role of sectarianism therein: Nikolaos van Dam's The Struggle for Power in Syria: Politics and Society under Asad and the Ba'th Party (1996). More problematic is the authors' portrayal of the PYD, the most significant Kurdish politico-military actor in the war (see, e.g., pp. 38-39, 147, 169, 175, 247). They frequently conflate it with the Kurdistan Workers' Party (PKK) and charge it with collaborating with the al-Assad regime without noting the alternative interpretation of its actions as pragmatic given a balance of power that favored the regime at the time. They do not acknowledge the enmity between Kurdish political parties in eastern Syria and the Kurdistan Regional Government in northern Iraq, which raises the possibility of anti-PYD bias in interviews with Iraqi respondents, many of which they used to characterize Kurdish politics and governance in Syria. And they assert that the PYD's agenda is transnational, without acknowledging its emphatic statements to the contrary, which have laid out a Syrian nationalist agenda (with a pluralist, not Arabist, understanding of Syrian nationality).

On research and reporting about Syria, the authors lament a lack of attention to the opposition's institution building, despite its prominence in Samer Abboud's Syria (2015), Robin Yassin-Kassab and Leila al-Shami's Burning Country: Syrians in Revolution and War (2016), and the reporting of journalists like Rania Abouzeid (see also her $N o$ Turning Back: Life, Loss, and Hope in Wartime Syria, 2018). They also contend that Emile Hokayem's Syria's Uprising and the Fracturing of the Levant (2013) implies that "the revolution [was] an expression of identitarian cleavages" (p. 17), despite passages in Hokayem to the opposite effect.

Finally, for readers unfamiliar with scholarship on civil war, I must flag the prefatory chapter as one whose discussion of positivist and rational choice research contains many mischaracterizations. The history of civil war studies in the modern social sciences is not as the authors portray it. Real-world strife tends to drive expansion in the volume of publications; the bulge from the 1990s on that they point to is linked to wars in the former Yugoslavia, Somalia, the post-Soviet space, Rwanda, Afghanistan, and Iraq, as well as the end of long-running conflicts in Africa and Latin America concurrent with the conclusion of the Cold War. The authors see the field during this time as increasingly "intent on [using] mathematical formalizations associated with quantitative studies" (pp. 2-3). But quantitative and formal research on civil war goes back generations; an early example is Bruce Russett's "Inequality and Instability: The Relation of Land Tenure to Politics," World Politics 16(3), 1964.

The chapter notes that the "lion's share" of studies are "produced by researchers with limited or no direct on-theground knowledge or even of the secondary literature dealing with the countries in question." The authors contend that these deficiencies and a failure to use "nonstructured interviews" results in "neopositivist" research that is "bereft of contextual knowledge [and] frequently ... incapable of putting forward sociologically relevant causes to explain the correlations found" (p. 3). Certainly, a substantial portion of civil war research does not involve trips to "the field." But the authors fail to mention that the mode of research they prefer has long been part of positivist and rational choice studies of civil war (for example, Robert W. White's "From Peaceful Protest to Guerrilla War: Micromobilization of the Provisional Irish Republican Army," American Journal of Sociology 94(6), 1989). A (recent) theoretical and empirical canon consists of studies that draw on extended field research, including unor semi-structured interviews. ${ }^{1}$ With the increasing prominence of studies that follow this mode of research, ${ }^{2}$ it is a stretch to attribute the pitfalls that the book identifies to "neopositivism" as such. Furthermore, does a lack of field research necessarily impoverish studies based on archival or secondary sources, ${ }^{3}$ formal modeling or statistical analysis? ${ }^{4}$ Does the absence of un- or semistructured interviews make field research-based studies that use survey or experimental methods less enlightening?

The quandary is that the book's overreaching presentation blunts the impact of its legitimate critiques. True, a positivist or rational choice study might display characteristics that the authors consider flawed-professional amnesia, reification of the objects of research, limitation of scope to objects that are readily observable, and epistemic closure (p. 3). But such flaws surely transcend research paradigms. Indeed, the authors' own writing provides examples of the flaws they rightly lament. The book's appendix table of interviews separates sect and ethnicity for Arabs and Turkmen, but not Kurds. The authors claim that the contribution of rational choice research on civil war "[has] been remarkably limited, particularly considering the scale of the resources 
expended" (p. 5) without providing supporting evidence. Has "game theory ... only very marginally contributed to clarifying the reality of the conflicts" (p. 5)? It is difficult to evaluate such a statement since the authors did not characterize the main questions of importance in the field of study, the contributions of game theory to date, and the extent to which the latter sheds light on the former. More importantly, the proposition lacks meaning without a counterfactual. Knowledge tends to accrete slowly, and at the margins. As scholars, what we may find more relevant than whether our contribution has been large in absolute terms is the extent of that contribution compared to what it might have been had we followed a different approach. The authors' charge that rational choice research displays "epistemic closure that translates into a refusal to regard other paradigms as scientific" (p. 3) can thus be leveled at their own sociological approach. If universally applicable concerns are legible to it as flaws only in positivist and rational choice approaches, then it derogates these as legitimate forms of knowledge production.

With such criticisms in mind, why do I recommend the book so widely? Civil War in Syria's marriage of field research-based empirical material and a strong theoretical framework allows us to learn deeply about that war, to place it in comparative perspective, and to think systematically about how to conduct empirical inquiries into it, other civil wars, and other dictatorships. The book stands as a powerful rejoinder to barefoot empiricism, demonstrating that "how we account for reality depends on the theoretical perspective we adopt" (p. 2).

The book's empirics also open windows into Syria during an important period in its history. The war's early years have been eclipsed in the public imagination by what followed, yet contain junctures that proved critical to the conflict's later trajectory; the authors' field research during them is thus invaluable. This is all the more so because, with the al-Assad regime looking closer and closer to victory, the memory of the opposition-controlled territories in which Baczko, Dorronsoro, and Quesnay conducted research is likely to be systematically overwrittenby the regime, but also by partisans of the opposition as they seek to explain what will be a devastating loss.

Civil War in Syria can be used fruitfully in undergraduate and graduate courses. Here, I speak from experience, having assigned it as required reading in two courses in spring 2018 - an advanced undergraduate seminar on varieties of political violence in the Middle East, and a Ph.D. seminar on civil war. Undergraduates engaged with the authors' arguments, even if they missed the nuances of methodological debates or quarrels within the literature. Graduate students, most of whom did not specialize on the Middle East or Syria, gained a better understanding of mobilization, governance, and war's systematic effects on individuals as topics in the comparative study of civil war, and learned a great deal about Syria to boot.
The book's prefatory chapter contains a trenchant critique of the study of civil war as a "sub-field that is more and more technicist, . . . fails to revisit its hypotheses, and, moreover, whose outputs are frequently repetitious and trivial" (p. 11). I hope that Baczko, Dorronsoro, and Quesnay's achievements with this book will promote productive dialogue within our community of scholars to help us see beyond theoretical and methodological disagreements in order to advance future research.

\section{Notes}

1 Reno 1998; Petersen 2001; Wood 2003; Doyle and Sambanis 2006; Kalyvas 2006; Straus 2006; Viterna 2006; Weinstein 2006.

2 Studies published from ten years ago through 2016, the latter selected as a cut-off because it would have made them available to Baczko, Dorronsoro, and Quesnay in writing their book, include the following (if a later publication date is listed, portions of the research were published no later than 2016): Fujii 2009; Giustozzi 2009; Metelits 2009; Autesserre 2010; Guichaoa 2010; Mampilly 2011; Pearlman 2011; Themnér 2011; Christia 2012; Leenders 2012; Hazen 2013; Savage 2013; Mukhopadhyay 2014; Staniland 2014; TunçerKılavuz 2014; Driscoll 2015; Mitton 2015; Arjona 2016; Cohen 2016; Daly 2016; Moncada 2016; Pearlman 2016; Roessler 2016; Souleimanov and Siroky 2016; Stanton 2016; Tamm 2016; Tezcür 2016; Ahmad 2017; Balcells 2017; Kaplan 2017; Krause 2017; Steele 2017; Szekely 2017; Hoover Green 2018; Woldemariam 2018.

3 Influential contributions to the field have taken this form, for example, Wickham-Crowley 1992; Goodwin 2001; Mueller 2003; Ross 2004; and Sinno 2007, which combines case studies based on secondary sources and statistical analysis. A recent example is Opper 2018, which uses archival sources on the Chinese Civil War, a conflict frequently referenced in passing but seldom studied by civil war scholars.

4 For example, Roemer 1985; Reynal-Querol 2002; Hegre and Sambanis 2006; Sambanis and SchulhoferWohl 2009; Berman et al. 2011; Cederman et al. 2011; Chacón, Robinson, and Torvik 2011; Sambanis and Shayo 2013; De Juan and Bank 2015; Gohdes 2015; Zhukov 2016.

5 For example, Fearon et. al. 2009; Paluck 2009; Alexander and Christia 2011; Gilligan et al. 2014; Cilliers et al. 2016; Verwimp 2003; Humphreys and Weinstein 2006; Ibáñez and Moya 2010; Corstange 2018.

\section{References}

Abboud, Samer N. 2015. Syria. Cambridge: Polity. 
Abouzeid, Rania. 2018. No Turning Back: Life, Loss, and Hope in Wartime Syria. New York: W.W. Norton.

Ahmad, Aisha. 2017. Jihad \& Co.: Black Markets and Islamist Power. New York: Oxford University Press.

Alexander, Marcus and Fotini Christia. 2011. "Context Modularity of Human Altruism.” Science 334(6061): 1392-94.

Arjona, Ana. 2016. Rebelocracy: Social Order in the Colombian Civil War. New York: Cambridge University Press.

Autesserre, Séverine. 2010. The Trouble with the Congo: Local Violence and the Failure of International Peacebuilding. New York: Cambridge University Press.

Balcells, Laia. 2017. Rivalry and Revenge: The Politics of Violence during Civil War. New York: Cambridge University Press.

Berman, Eli, Jacob N. Shapiro, and Joseph H. Felter. 2011. "Can Hearts and Minds Be Bought? The Economics of Counterinsurgency in Iraq." Journal of Political Economy 199(4): 766-819.

Cederman, Lars-Erik, Nils B. Weidmann, and Kirstian Skrede Gleditsch. 2011. "Horizontal Inequalities and Ethnonationalist Civil War: A Global Comparison.” American Political Science Review 105(3): 478-495.

Chacón, Mario, James A. Robinson, and Ragnar Torvik. 2011. "When Is Democracy an Equilibrium? Theory and Evidence from Colombia's La Violencia." Journal of Conflict Resolution 55(3): 366-96.

Christia, Fotini. 2012. Alliance Formation in Civil Wars. New York: Cambridge University Press.

Cilliers, Jacobus, Oeindrila Dube, and Bilal Siddiqi. 2016. "Reconciling After Civil Conflict Increases Social Capital But Decreases Individual Well-Being." Science 352(6287): 787-794.

Cohen, Dara Kay. 2016. Rape during Civil War. Ithaca, NY: Cornell University Press.

Corstange, Daniel. 2018. "The Syrian Conflict and Public Opinion among Syrians in Lebanon." British Journal of Middle Eastern Studies. DOI: 10.1080/ 13530194.2017.1403307.

Daly, Sarah Zukerman. 2016. Organized Violence after Civil War: The Geography of Recruitment in Latin America. New York: Cambridge University Press.

De Juan, Alexander and André Bank. 2015. "The Ba athist Blackout? Selective Goods Provision and Political Violence in the Syrian Civil War." Journal of Peace Resesarch 52(1): 91-104.

Doyle, Michael W. and Nicholas Sambanis. 2006. Making War and Building Peace: United Nations Peace Operations. Princeton: Princeton University Press.

Driscoll, Jesse. 2015. Warlords and Coalition Politics in PostSoviet States. New York: Cambridge University Press.

Fearon, James D., Macartan Humphreys, and Jeremy M. Weinstein. "Can Development Aid Contribute to Social Cohesion after Civil War? Evidence form a Field
Experiment in Post-Conflict Liberia." American Economic Review 99(2): 287-291.

Fujii, Lee Ann. 2009. Killing Neighbors: Webs of Violence in Rwanda. Ithaca, NY: Cornell University Press.

Gilligan, Michael J., Benjamin J. Pasquale, and Cyrus Samii. 2014. "Civil War and Social Cohesion: Lab-inthe-Field Evidence from Nepal." American Journal of Political Science 58(3): 604-19.

Giustozzi, Antonio. 2009. Empires of Mud: Wars and Warlords in Afghanistan. New York: Columbia University Press.

Gohdes, Anita R. 2015. "Pulling the Plug: Network Disruptions and Violence in Civil Conflict." Journal of Peace Research 52(3): 352-67.

Goodwin, Jeff. 2001. No Other Way Out: States and Revolutionary Movements, 1945-1991. New York: Cambridge University Press.

Guichaoa, Yvan. 2010. "How Do Ethnic Militias Perpetuate in Nigeria? A Micro-level Perspective on the Oodua People's Congress.” World Development 38(11): 1657-66.

Hazen, Jennifer M. 2013. What Rebels Want: Resources and Supply Networks in Wartime. Ithaca, NY: Cornell University Press.

Hegre, Håvard and Nicholas Sambanis. 2006. "Sensitivity Analysis of the Empirical Results on Civil War Onset." Journal of Conflict Resolution 50(4): 508-535.

Hokayem, Emile. 2013. Syria's Uprising and the Fracturing of the Levant. London: IISS.

Hoover Green, Amelia. 2018. The Commander's Dilemma: Violence and Restraint in Wartime. Ithaca, NY: Cornell University Press.

Humphreys, Macartan and Jeremy M. Weinstein. 2006. "Handling and Manhandling Civilians in Civil War." American Political Science Review 100(3): 429-47.

Ibáñez, Ana María and Andés Moya. 2010. "Vulnerability of Victims of Civil Conflicts: Empirical Evidence for the Displaced Population in Colombia." World Development 38(4): 647-63.

Kalyvas, Stathis N. 2006. The Logic of Violence in Civil War. New York: Cambridge University Press.

Kaplan, Oliver. 2017. Resisting War: How Communities Protect Themselves. New York: Cambridge University Press.

Krause, Peter. 2017. Rebel Power: Why National Movements Compete, Fight, and Win. Ithaca, NY: Cornell University Press.

Leenders, Reinoud. 2012. "Collective Action and Mobilization in Dar'a: An Anatomy of the Onset of Syria's Popular Uprising." Mobilization 17(4): 419-34.

Mampilly, Zachariah Cherian. 2011. Rebel Rulers: Insurgent Governance and Civilian Life during War. Ithaca, NY: Cornell University Press. 
Metelits, Claire. 2009. Inside Insurgency: Violence, Civilians, and Revolutionary Group Behavior. New York: New York University Press.

Mitton, Kieran. 2015. Rebels in a Rotten State: Understanding Atrocity in the Sierra Leone Civil War. New York: Oxford University Press.

Moncada, Eduardo. 2016. Cities, Business, and the Politics of Urban Violence in Latin America. Stanford: Stanford University Press.

Mueller, John. 2003. The Remnants of War. Ithaca, NY: Cornell University Press.

Mukhopadhyay, Dipali. 2014. Warlords, Strongman Governors, and the State in Afghanistan. New York: Cambridge University Press.

Opper, Marc. 2018. "Revolution Defeated: The Collapse of the Chinese Soviet Republic." Twentieth-Century China 43(1): 45-66.

Paluck, Elizabeth Levy. 2009. "Reducing Intergroup Prejudice and Conflict Using the Media: A Field Experiment in Rwanda." Journal of Personality and Social Psychology 96(3): 574-87.

Pearlman, Wendy. 2011. Violence, Nonviolence, and the Palestinian National Movement. New York: Cambridge University Press.

_ 2016. "Narratives of Fear in Syria." Perspectives on Politics 14(1): 21-37.

Petersen, Roger D. 2001. Resistance and Rebellion: Lessons from Eastern Europe. New York: Cambridge University Press.

- 2002. Understanding Ethnic Violence: Fear, Hatred, and Resentment in Twentieth Century Europe. New York: Cambridge University Press.

Reno, William. 1998. Warlord Politics and African States. Boulder, CO: Lynne Rienner.

Reynal-Querol, Marta. 2002. "Ethnicity, Political Systems, and Civil Wars." Journal of Conflict Resolution 46(1): 29-54.

Roemer, John E. 1985. "Rationalizing Revolutionary Ideology.” Econometrica 53(1): 85-108.

Roessler, Philip. 2016. Ethnic Politics and State Power in Africa: The Logic of the Coup-Civil War Trap. New York: Cambridge University Press.

Ross, Michael L. 2004. "How do Natural Resources Influence Civil War? Evidence from Thirteen Cases." International Organization 58(1): 35-67.

Russett, Bruce M. 1964. "Inequality and Instability: The Relation of Land Tenure to Politics." World Politics 16(3): 442-54.

Sambanis, Nicholas and Jonah Schulhofer-Wohl. 2009. "What's in a Line? Is Partition a Solution to Civil War?" International Security 34(2): 82-118.

Sambanis, Nicholas and Moses Shayo. 2013. "Social Identification and Ethnic Conflict." American Political Science Review 107(2): 294-325.
Savage, James D. 2013. Reconstructing Iraq's Budgetary Institutions: Coalition State Building After Saddam. New York: Cambridge University Press.

Sinno, Abdelkader H. 2007. Organizations at War in Afghanistan and Beyond. Ithaca, NY: Cornell University Press.

Souleimanov, Emil Aslan and David S. Siroky. 2016. "Random or Retributive? Indiscriminate Violence in the Chechen Wars." World Politics 68(4): 677-712.

Staniland, Paul. 2014. Networks of Rebellion: Explaining Insurgent Cohesion and Collapse. Ithaca, NY: Cornell University Press.

Stanton, Jessica A. 2016. Violence and Restraint in Civil War: Civilian Targeting in the Shadow of International Law. New York: Cambridge University Press.

Steele, Abbey. 2017. Democracy and Displacement in Colombia's Civil War. Ithaca, NY: Cornell University Press.

Straus, Scott. 2006. The Order of Genocide: Race, Power, and War in Rwanda. Ithaca, NY: Cornell University Press.

Szekely, Ora. 2017. The Politics of Militant Group Survival in the Middle East: Resources, Relationships, and Resistance. New York: Palgrave Macmillan.

Tamm, Henning. 2016. "The Origins of Transnational Alliances: Rulers, Rebels, and Political Survival in the Congo Wars.” International Security 41(1): 147-81.

Tezcür, Güneş Murat. 2016. "Ordinary People, Extraordinary Risks: Participation in an Ethnic Rebellion." American Political Science Review 110(2): 247-64.

Themnér, Anders. 2011. Violence in Post-Conflict Societies: Remarginalization, Remobilizers and Relationships. New York: Routledge.

Tunçer-Kılavuz, Idil. 2014. Power, Networks and Violent Conflict in Central Asia: A Comparison of Tajikistan and Uzbekistan. New York: Routledge.

van Dam, Nikolaos. 1996. The Struggle for Power in Syria: Politics and Society under Asad and the Ba'th Party. London: I.B. Tauris.

Verwimp, Philip. 2003. "Testing the Double-Genocide Thesis for Central and Southern Rwanda." Journal of Conflict Resolution 47(4): 423-42.

Viterna, Jocelyn. 2006. "Pulled, Pushed, and Persuaded: Explaining Women's Mobilization into the Salvadoran Guerrilla Army." American Journal of Sociology 112(1): $1-45$.

- 2013. Women in War: The Micro-Processes of Mobilization in El Salvador. New York: Oxford University Press.

Weinstein, Jeremy M. 2006. Inside Rebellion: The Politics of Insurgent Violence. New York: Cambridge University Press. 
White, Robert W. 1989. "From Peaceful Protest to Guerrilla War: Micromobilization of the Provisional Irish Republican Army." American Journal of Sociology 94(6): 1277-1302. Wickham-Crowley, Timothy P. 1992. Guerrillas and Revolution in Latin America: A Comparative Study of Insurgents and Regimes since 1956. Princeton: Princeton University Press.

Woldemariam, Michael. 2018. Insurgent Fragmentation in the Horn of Africa: Rebellion and Its Discontents. New York: Cambridge University Press.
Wood, Elisabeth Jean. 2003. Insurgent Collective Action and Civil War in El Salvador. New York: Cambridge University Press.

Yassin-Kassab, Robin and Leila al-Shami. 2016. Burning Country: Syrians in Revolution and War. London: Pluto Press.

Zhukov, Yuri. 2016. "Trading Hard Hats for Combat Helmets: The Economics of Rebellion in Eastern Ukraine." Journal of Comparative Economics 44(1): 1-15. 